\title{
Entrepreneurial Intention Determinants: An Empirical Model and a Case of Iranian Students in Malaysia
}

\section{Abdolhamid Papzan*,Nashmil Afsharzade**, Khadijeh Moradi***}

\begin{abstract}
This study investigated entrepreneurial intention among graduate students of USM**** Engineering Campus. Applying the Theory of Planned Behavior (TPB; Ajzen), we examined the empirical model of entrepreneurial intention determinants. Although research has been conducted in entrepreneurial intention, limited study has been done among Iranian graduate students who are studying abroad. This research aims to fill this gap using Entrepreneurial Intention Questionnaire (EIQ, version 3.1). Accordingly, a survey study was applied and Iranian graduate students of the USM Engineering Campus were studied using the census method. The authors propose an empirical model and tested its reliability and validity using structural equation modeling. Data was analyzed using Spss16 and Amos18 software. Results revealed that the level of knowledge about business sources of assistance for entrepreneurs in addition to components of the TPB, affected entrepreneurial intention. Empirical model 's goodness of fit indices indicated good model fit $\chi 2=1.047, d f=2$, probability 0.592; NFI=0.981; CFI=1.000; RMSEA=0.000). It seems that current empirical model could be a guide for future research on this important topic.
\end{abstract}

Keywords: entrepreneurial intention, structural equation modeling, graduate students, TPB.

\section{Introduction}

The unemployment crisis in many countries is considered a major problem, even in advanced industrial countries. This problem can be considered as an economic illness (Kazemirad, Papzan, 2011 quoted by Ahmadzade) in developing countries, especially in our country which faces severe conditions. Each year eight hundred thousand jobseekers enter the labor market, which

\footnotetext{
* Associate Professor and member of Socio-Economic Research Center, College of Agriculture, Razi University, P.O.Box 1158.post code: 67155,Kermanshah, Iran, papzanabdolhamid89@gmail.com.

** Ph.D. Student of Agricultural Development, College of Agriculture, Razi University of Kermanshah, nashmilafsharzade@yahoo.com.

*** Ph.D. Student of Agricultural Development, College of Agriculture, Razi University of Kermanshah, sepidar_m2003@yahoo.com.

**** Universiti Sains Malaysia, Engineering Campus is in Penang, Malaysia.
} 
constitutes one of the main challenges in social-economic development in Iran. In fact, unemployment crisis is a threat to the whole society, especially unemployment among university graduates will have the noncompensation consequences in social, economic, and political dimensions. According to statistics, every year 270 thousand university graduates enter the job market, but the market capacity does not fulfill their employment needs (Shiri, et al., 2012). One strategy that has helped many developed and developing countries to overcome the problem of unemployment, has been the development of entrepreneurship (Hosseini, Ahmadi, 2011). It has been recognized as an important element in the dynamics of modern economies (Movahedi, Fathi, 2011).

Nowadays, entrepreneurship has developed globally in the field of industrial, manufacturing and service sectors (Heidary, et al., 2011 quoted by Parker). Entrepreneurship is a process that creates opportunities for educated people allowing them to achieve financial independence through increased innovation and new business opportunities (Souitaris, et al., 2007). Therefore, most universities are spending significant amounts of money to design a viable entrepreneurship education for their students. Harrison and Leitch (1994) analyzed the evolution of entrepreneurship education in a threestage model. According to this model, the first approach to entrepreneurial education is to view it as a sub-set of general management education. As a reaction to this approach, the second view differentiates entrepreneurial education from the managements of large-scale organizations. The last stage provides a basis for the notion of the reintegration of management education and entrepreneurship education (Harrison, Leitch, 1994). Recently, the nature of discussion on entrepreneurial education has been shifting towards learning entrepreneurship and not about entrepreneurship itself (Cooper, 2004). Since it is difficult to find one-fits-all model for all cases, the disagreement on the issue might continue in the future as well. However, the concrete progress in entrepreneurial education during the last decades shows that these discussions are important for shaping future understandings (Gelard, Emami Saleh, 2011).

The previous studies in the literature indicated a link between education and entrepreneurship (Galloway, Brown, 2002; Henderson, Robertson, 2000). As such, receiving an adequate education may foster the entrepreneurial intention of a person. According to Garavan and O'Cinneide (1994), there is clearly a major role and need for entrepreneurship education and training. Since the education offered by a university mostly influences the career selection of students, universities can be seen as potential sources of future entrepreneurs (Gelard, Emami Saleh, 2011). Based on this fact, the entrepreneurial behavior is a result of intentions and desires of the people, 
and, intention is prior to behavior; in this study, entrepreneurial intentions are considered as the main variable and graduate student were selected to study. Entrepreneurial intention is a state of mind that guides individual actions in order to create and develop a new business or entrepreneurial activity (Shiri, et al., 2012). It is also a valid tool for forecasting individual entrepreneurial conducts and activities (Krueger, Carsrud, 2000).One theory that tries to explain intentional behavior is the Theory of Planned Behavior (TPB). This theory, grounded in social psychology, is based on the premise that much human behavior is planned and is therefore preceded by intention toward that behavior (Fishbein, Ajzen, 1975). It asserts that intention is an accurate predictor of planned behavior, especially in cases where the behavior is difficult to observe, rare, or involves unpredictable time lags. Entrepreneurial behavior displays these characteristics, which explains why several empirical studies of entrepreneurship have applied the theory of planned behavior to the study of entrepreneurship from a psychological perspective (see for example, Kolvereid, Isaksen, 2006; Rotefoss, Kolveried, 2005; Krueger et al., 2000; Souitaris et al., 2007). According to Kreuger et al., (2000), entrepreneurial activity can be predicted more accurately by studying intention rather than personality traits, demographic characteristics, or situational factors.

Several theories have attempted to elucidate the determinants of entrepreneurial intention. The theory of planned behavior contends that intentions are a function of three sets of factors: attitudes toward behavior, subjective norms, and perceived behavioral control (PBC). Attitudes are defined as beliefs and perceptions regarding the personal desirability of performing the behavior, which are in turn related to expectations regarding the personal impact of outcomes resulting from that behavior (Ajzen, 1991). Subjective norms or perceived social norms are defined as individuals' perceptions about the values, beliefs, and norms held by people whom they respect or regard as important and the individuals' desire to comply with those norms. It is argued that social norms are less predictive of intentions for individuals who have a high internal locus of control (Krueger, et al., 2000). PBC is defined as the personal belief about being able to execute planned behavior and the perception that the behavior is within the decision maker's control. It is similar to Bandura's (1986) concept of self-efficacy.

In the context of entrepreneurship, the theory of planned behavior asserts that entrepreneurial intention is dependent on an individual's attitude toward the desirability of an entrepreneurial career, subjective norms including perceived family expectations and beliefs to perform the behavior, and perceived behavioral control or the perceived ability to execute the intended behavior of entering entrepreneurship. According to Moriano, et al., (2011) 
The TPB has been used successfully in the past to describe entrepreneurial intentions of students in the U.S. (Autio, et al., 2001; Krueger et al., 2000), The Netherlands (Van Gelderen et al., 2008), Norway (Kolvereid, 1996), Russia (Tkachev, Kolvereid, 1999), Finland, Sweden (Autio, et al., 2001), Germany (Jacob, Richter, 2005), Spain and Taiwan (Liñán, Chen, 2009; Moriano, 2005), and South Africa (Gird, Bagraim, 2008). But can this be successful in explaining entrepreneurial intentions of Iranian students? Developing countries, such as Iran, have a different psychological perspective of TPB. Our research was conducted with an aim of responding to that question, focusing on Iranian graduate student in USM.

\section{Methodology}

The population of the study included all Iranian graduate students (Master and $\mathrm{PhD}$ ) of USM Engineering Campus in Malaysia ( $\mathrm{N}=51$ (who were studying in 2011. These students can be viewed as being future experts and decisionmakers in the field of entrepreneurship. Because of the small population, all of them were studied through census study. The Entrepreneurial Intention Questionnaire (EIQ, version 3.1) was originally developed in Spain by Moriano (2005). The EIQ comprises four subscales: attitudes towards entrepreneurship, subjective norms, $\mathrm{PBC}$, and entrepreneurial intention. The third TPB component, perceived behavioral control (PBC), refers to people's perceptions of their ability to perform a given behavior. Individuals usually choose to perform behaviors that they think they will be able to control and master. This concept is therefore very similar to self-efficacy (or even the same, see Bandura, 1982). Both concepts concerned the perceived ability to perform a behavior, e.g., starting a new business. In their review of TPB, Armitage and Conner (2001) conclude that self-efficacy is more clearly defined and more strongly correlated with intentions than PCB. In fact, self-efficacy has replaced PBC in numerous studies (Krueger et al., 2000; Kolvereid, Isaksen, 2006; Moriano, 2005; Van Gelderen et al., 2008). The Cronbach alpha reliability of the EIQ subscales in previous research ranged from .76 to .87 in the Spanish sample of 281 students and from .77 to .87 in the Polish sample of 154 students (Laguna et al., 2008). EIQ was translated from English to Persian using a back-translation procedure (Hambleton, 1994). First, one collaborator translated the English version to Persian. After this, a professional translator performed the back translation of the Persian version into English. The original and back-translated English version were compared and adjusted, and the final Persian version was agreed upon by all translators. According to entrepreneurial challenges faced by entrepreneurs in developing countries such as Iran, it seems that knowledge about business 
associations for entrepreneurs may affect entrepreneurial intention in addition to TPB components. This construct was measured with six items:

- Private association, NGOs and consultant firms

- Public support bodies

- Specific training for young entrepreneur

- Loans on specially favorable terms

- Technical aids for business start-ups

- Business centers

In this study Cronbach alpha for each scale was shown in Table 1. According to the table, Cronbach alpha for each of the scale used in the study should be equal to or higher than 0.7 . Therefore, all the scales were reliable.

Table 1. Cronbach's alpha for reliability verification

\begin{tabular}{lc}
\hline Components & Chronbach's alpha \\
\hline Subjective norm & 0.76 \\
Knowledge about business associations & 0.79 \\
Self efficacy & 0.80 \\
Attitude toward behavior & 0.86 \\
\hline
\end{tabular}

The measures were subjected to path analysis. As each of the variable included in the path analysis should have normal distribution, Shapiro - Wilk test was performed, as the sample of 51 is too small. Based on Table 2, all of the independent variables were appropriate for the path model.

Table 2. Tests of normality

\begin{tabular}{lcccccc}
\hline & \multicolumn{3}{c}{ Kolmogrov- smirnova } & \multicolumn{3}{c}{ Shapiro-wilk } \\
\hline & Statistic & df & Sig. & Statistic & df & Sig. \\
Self efficacy & .167 & 51 & .001 & .926 & 51 & .230 \\
Knowledge about business & .092 & 51 & $.200^{*}$ & .947 & 51 & .310 \\
association & & & & & & \\
Subjective norm & .078 & 51 & $.200^{*}$ & .985 & 51 & .753 \\
Attitude toward behavior & .178 & 51 & .000 & .922 & 51 & .140 \\
\hline
\end{tabular}

* This is a lower bound of the true significance.

a. Lilliefors significance correction.

Moreover, homoscedascity of variances of residues was verified using Durbin - Watson test and can be found in the last column of model summary table. This statistics informs us about whether assumption of independent error is tenable. If this statistics be between $1 / 5-2 / 5$ indicated assumption will be verify. For these data the value is 1.607 , thus the assumption has been met (Table 3). 
Table 3. Mode summary table for Durbin - Watson test

Model sumary

\begin{tabular}{|c|c|c|c|c|c|c|c|c|c|c|}
\hline \multirow[b]{2}{*}{ Model } & \multirow[b]{2}{*}{$\mathbf{R}$} & \multirow[b]{2}{*}{$\begin{array}{c}\mathbf{R} \\
\text { Square }\end{array}$} & \multirow{2}{*}{$\begin{array}{c}\text { Adjuster } \\
\text { R } \\
\text { Square }\end{array}$} & \multirow{2}{*}{$\begin{array}{l}\text { Std. } \\
\text { Error } \\
\text { of the } \\
\text { Estimate }\end{array}$} & \multirow{2}{*}{$\begin{array}{c}R \\
\text { Square } \\
\text { change }\end{array}$} & \multicolumn{3}{|c|}{ Change Statistics } & \multirow[b]{2}{*}{$\begin{array}{l}\text { Sig. F } \\
\text { Change }\end{array}$} & \multirow[b]{2}{*}{$\begin{array}{l}\text { Durbin } \\
\text { Watson }\end{array}$} \\
\hline & & & & & & $\begin{array}{c}\mathbf{F} \\
\text { Change }\end{array}$ & df1 & df2 & & \\
\hline 1 & $.770^{a}$ & .593 & .558 & .54181 & .593 & 17.752 & 4 & 46 & .000 & 1.607 \\
\hline
\end{tabular}

a. Predictors: (Constant), attitudetowardthebehavior, knowledgeaboutbusinessassociations, selfefficacy, subjectivenorma.

b. Dependent Variable: intentionb.

We formed composite measures for each construct in the model by averaging scores across items representing that measure.

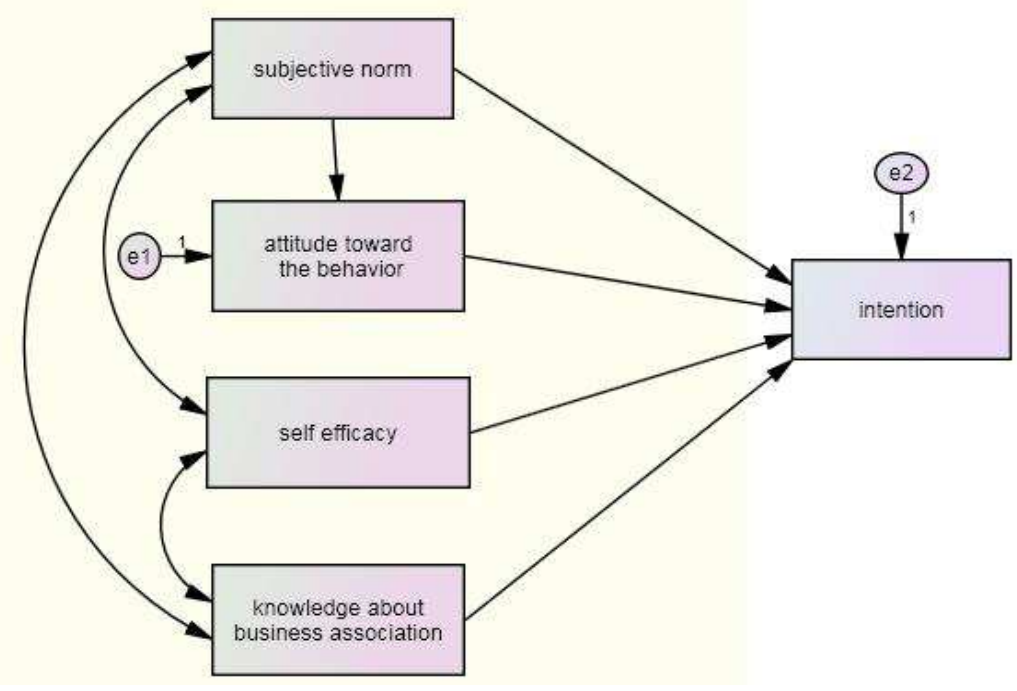

Figure 1. Proposed entrepreneurial intention model

The empirical model was tested using AMOS18 software. The goodness of the fit of the models was evaluated using the $\chi 2$ goodness of fit statistics, the Normed Fit Index (NFI) and the Comparative Fit Index (CFI). The model $\chi 2$ higher values reflect the model's worse correspondence to the data. For both relative fit-indices, as a rule of thumb, values greater than .90 are considered as indicating a good fit (Byrne, 2001, pp. 79-88). In addition, the Root Mean Square Error of Approximation (RMSEA) is computed for which values up to .08 indicate a reasonable fit of the model (Browne, Cudeck, 1992). 


\section{Findings}

In order to determine the effect of independent variables on entrepreneurial intentions, Path Analysis Techniques were employed. Path analysis is multivariate technique that is used to describe both direct effects and indirect effects of independent variables on the dependent variable (Shiri, et al., 2012 quoted by Kalantari). Therefore, in this study, social norms, attitude toward behavior, self-efficacy and knowledge about business associations as independent variables and entrepreneurial intentions as a dependent variable were analyzed. The Path coefficients of the research variables are presented in figure 2 . Table 4 shows direct effects, indirect effects and total effects of independent variables on entrepreneurial intentions among Iranian graduate students in USM. The direct effect equals beta coefficient in multiple regression analysis. The indirect effect of each variable equals multiplying path coefficients of all variables in a path which leads to a dependent variable. The total effect is a sum of direct and indirect effects of each variable that were presented in the path analysis diagram in Table 4. According to path coefficients which are shown in Table 4, social norms can be considered as the most important predictor of entrepreneurial intention in this study (total effect $=0.48$ ). The second determinant of entrepreneurial intention is knowledge about business associations. Self efficacy and attitude toward behavior with total effect of 0.20 and 0.16 are the other factors affected Iranian graduate students in USM, respectively.

Table 4. Summary of information relevant to the analysis of research variables

\begin{tabular}{lccc}
\hline Components & Direct effect & Indirect effect & Total effect \\
\hline subjective norms & 0.36 & 0.12 & 0.48 \\
knowledge about business & 0.29 & - & 0.29 \\
associations & 0.20 & - & 0.20 \\
Self efficacy & 0.16 & - & 0.16 \\
Attitude toward behavior & &
\end{tabular}

Based on the Table 2, 72.5 percent of the sample from Iranian graduate students in USM Engineering Campus were male and their average age was 31. 70.6 percent of students' fathers' education was higher education and 22 percent of their fathers' present occupation was self employment and private employment (18 and 4 percent, respectively). About 47 percent of respondent have been self-employed or the owner of a small or medium sized enterprise. 
Table 5. Sample description

\begin{tabular}{|c|c|c|c|c|c|c|}
\hline Variable & Categories & Frequency & Percent & $\begin{array}{c}\text { Valid } \\
\text { percent }\end{array}$ & $\begin{array}{c}\text { Cumulative } \\
\text { percent }\end{array}$ & Mean \\
\hline Gender & $\begin{array}{l}\text { Male } \\
\text { Female } \\
\text { Total }\end{array}$ & $\begin{array}{l}37 \\
14 \\
51\end{array}$ & $\begin{array}{l}72.5 \\
27.5 \\
100\end{array}$ & $\begin{array}{l}72.5 \\
27.5 \\
100\end{array}$ & $\begin{array}{l}72.5 \\
100\end{array}$ & \\
\hline $\begin{array}{l}\text { Father's } \\
\text { education }\end{array}$ & $\begin{array}{l}\text { Primary } \\
\text { Secondary } \\
\text { Diploma } \\
\text { Higher education } \\
\text { Missing } \\
\text { total }\end{array}$ & $\begin{array}{c}6 \\
2 \\
5 \\
36 \\
2 \\
51\end{array}$ & $\begin{array}{c}11.8 \\
3.9 \\
9.8 \\
70.6 \\
3.9 \\
100\end{array}$ & $\begin{array}{c}11.8 \\
3.9 \\
9.8 \\
70.6 \\
3.9 \\
100\end{array}$ & $\begin{array}{l}11.8 \\
15.7 \\
25.5 \\
96.1 \\
100\end{array}$ & 31 \\
\hline $\begin{array}{l}\text { Father's } \\
\text { present } \\
\text { occupation }\end{array}$ & $\begin{array}{l}\text { Private sector } \\
\text { employee } \\
\text { Public sector } \\
\text { employee } \\
\text { Self employed or } \\
\text { entrepreneur } \\
\text { Retired } \\
\text { Unemployment } \\
\text { Missing } \\
\text { total }\end{array}$ & $\begin{array}{c}2 \\
9 \\
9 \\
30 \\
50 \\
1 \\
51\end{array}$ & $\begin{array}{c}3.9 \\
17.6 \\
17.6 \\
58.8 \\
98.0 \\
2.0 \\
100\end{array}$ & $\begin{array}{c}4 \\
18 \\
18 \\
60 \\
100\end{array}$ & $\begin{array}{c}4 \\
22 \\
40 \\
100\end{array}$ & \\
\hline $\begin{array}{l}\text { Students' } \\
\text { self } \\
\text { employment } \\
\text { and owner } \\
\text { of a SME }\end{array}$ & $\begin{array}{l}\text { Yes } \\
\text { No } \\
\text { Missing } \\
\text { Total }\end{array}$ & $\begin{array}{c}23 \\
\\
26 \\
49 \\
2 \\
51\end{array}$ & $\begin{array}{c}45.1 \\
\\
51.0 \\
96.1 \\
3.9 \\
100\end{array}$ & $\begin{array}{c}46.9 \\
\\
53.1 \\
100\end{array}$ & $\begin{array}{l}46.9 \\
100\end{array}$ & \\
\hline
\end{tabular}

As shown in the figure 2, there is a reasonable fit of the four-factor model to the data on the basis of a number of fit statistics $(\chi 2=1.047, d f=2$, probability 0.592; NFI= 0.981; $\mathrm{CFI}=1.000 ; \mathrm{RMSEA}=0.000$ ). Figure 2 depicts the model which includes proposed relationship and results of the model test in Amos software ( $\beta$ coefficients). 


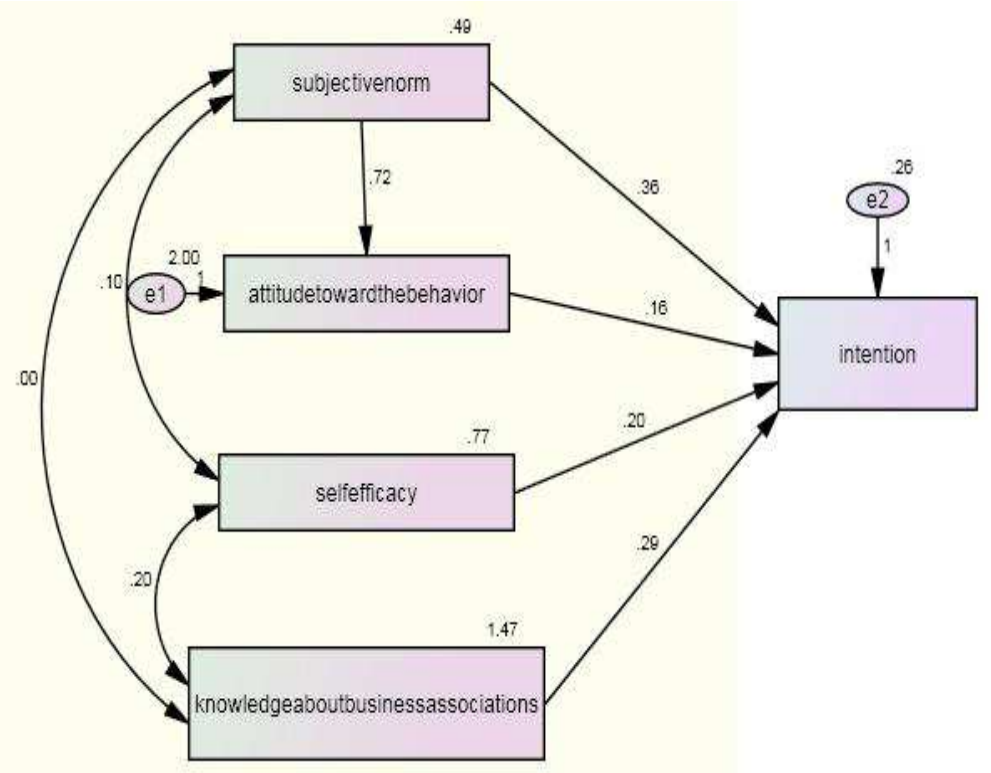

Figure 2. The empirical path model of entrepreneurial intention

\section{Discussion and conclusion}

The aim of this study was to investigate determinants of entrepreneurial intention among graduate students of the USM Engineering Campus. Remarkable results of this study were the important direct and indirect effect of social norm on entrepreneurial intention. This conclusion is in line with the studies of (Degeorge, Fayolle, 2008; Barani, Zarafshani, 2009; Barani et al., 2010; Nsurdin et al., 2009) but, it is in opposition to the results of Shiri et al., (2012). This difference may be due to the different statistical population in terms of their level of education (undergraduate students) and the place of the study. They found that relationship between social norms and entrepreneurial intentions among undergraduate students of llam University (Iran) were not significant, because in societies such as Iran, families prefer to work in public sector rather than private sectors or entrepreneurial ventures (Javadian, Dastmalchian, 2003).

Our results further show that in addition to components of the TPB, knowledge about business associations affected entrepreneurial intention. Therefore, it seems that this study enriches the past entrepreneurial intentions literature. We demonstrated that for graduate students entrepreneurial intentions is not only related to the attitude, social norms and self efficacy, but is also affected by knowledge about business associations. The cause of these findings may be related to economic challenges in developing countries such as limited personal and family savings and an absence of financial innovation which severely limits the growth prospects of promising startups. 
In these countries, odds of a new enterprise surviving its first five years are less than $50 \%$, is it rational for an entrepreneur to commit financial resources. Successful entrepreneurs are likely to find ways to access the greater pools of private saving in the countryside in order to start their businesses. This highlights the possible importance of knowledge about business associations for entrepreneurs in developing countries such as Iran.

The result of this study has implications for entrepreneurial policymakers in Iran. They need to be cognizant of importance of knowledge about business associations and entrepreneurial intentions. It is therefore recommended that supportive organization such as banks, business centers etc. announce their services and universities should have effective interaction with these centers. This would help to increase entrepreneurial intention among potential entrepreneur to create knowledge-based enterprise and mitigate unemployment challenges, especially among graduate students. Moreover, access to information about business associations helps students staying abroad to return and decreases the brain drain problem. Finally, according to the literature, the existing models of entrepreneurship are based largely on research conducted in the United States and other developed countries and do not adequately describe how entrepreneurship is carried out in developing countries. Thus, entrepreneurial intention model must be indigenized, as empirical model that proposed in this study. Due to empirical testing, situational variables can be studied (Krueger, Carsrud, 1993).

\section{References}

Armitage, C. J., Conner, M. (2001). Efficacy of the theory of planned behaviour: a metaanalytic review. British Journal of Social Psychology, 40, 471-499.

Ajzen, I. (1991). Theory of planned behavior. Organizational Behavior and Human Decision Processes, 50, 179-211.

Bandura, A. (1986). The Social Foundations of Thought and Action. Englewood Cliffs: Prentice Hall.

Bandura, A. (1982). Self-efficacy mechanism in human agency. American Psychologist, 37,122-147.

Barani, Sh., Zarafshani, K. (2009). a determination of the effect of attitude towards entrepreneurship, social norms, and self efficacy in predicting entrepreneurial intention among rural development management students at Payame-Noor University, Kermanshah. Iranian Journal of Agricultural Economics and Development, 40-2(3), 91-99.

Barani, Sh., Zarafshani, K., Del-Angizan, S., Hosseini Largani, S. M. (2010). The influence of entrepreneurship education on entrepreneurial behavior of college students in Kermanshah's Payam-Noor University: Structural Equation Modeling Approach. Quarterly Journal of Research and Planning in Higher Education, 16(3), 85-105. 
Browne, M. W., Cudeck, R. (1992). Alternative ways of assessing model fit. Sociological Methods and Research, 21, 230-258.

Cooper, S., Bottomley, C., Gordon, J. (2004). Stepping out of the classroom and up the ladder of learning: an experimental learning approach to entrepreneurship education. Industry and Higher Education, 8(1), 11-22.

Degeorge, J. M., Fayolle, A. (2008). Is entrepreneurial intention stable through time? First insights from a sample of French students. International Journal of Entrepreneurship and Small Business, 5 (1), 7-27.

Douglas, E.J., Shepherd, D.A. (2002). Self-employment as a career choice: Attitudes, entrepreneurial intentions, and utility maximization. Entrepreneurship: Theory and Practice, 26(3), 81-90.

Fishbein, M., Ajzen, I. (1975). Belief, attitude, intention and behavior: An introduction to theory and research. Reading, MA: Addison-Wesley.

Galloway, L., Brown, W. (2002). Entrepreneurship education at university: a driver in the creation of high growth firms. Education+Training, 44(8/9), 398-405.

Haidari, H., Papzan, A., Karami Darabkhani, R. (2011). Examine the relationship between organizational culture and organizational entrepreneurship components: a case of JAHAD-E-Agriculture Organization of Kermanshah Township. Quarterly of Innovation and Creativity in Human Science, 1(3), 45-166.

Hambleton, R. K. (1994). Guidelines for adapting educational and psychological tests: a progress report. European Journal of Psychological Assessment, $10,229-244$.

Harrison, R. T., Leitch, C.M. (1994). Entrepreneurship and leadership: the implications for education and development. Entrepreneurship and Regional Development, 6, 11-215.

Henderson, R., Robertson, M. (2000). Who wants to be an entrepreneur? Young adult attitudes to entrepreneurship as a career. Career Development International, 5(6), 279-87.

Javadian, M. \& Dastmalchian, A. (2003). Culture and leadership in Iran: The land of individual achievers, strong family ties, and powerful elite. Academy of Management Executive, 17, 127-142.

Juan A. M. L., Gorgievski, M., Laguna, M., Stephan, Ute., Zarafshani, K. (2011). A cross-cultural approach to understanding entrepreneurial intention. Forthcoming Journal of Career Development, 1-30. Doi: 10.1177/0894845310384481.

Kazemirad, Z., Papzan, A. (2011). Predicting success of rural entrepreneurship in Kermanshah city using Artificial Neural Network (ANN). Journal of Zonal Planning, 1(1), 17-25.

Krueger, N. \& A. Carsrud (1993). Entrepreneurial intentions: applying the theory of planned behavior. Entrepreneurship \& Regional Development, 5(4), 315-330. 
Krueger, N.F. (2000). The cognitive infrastructure of opportunity emergence. Entrepreneurship Theory \& Practice, 24, 5-23.

Krueger, N. F., Reilly, M. D., Carsrud, A. L., (2000). Competing models of entrepreneurial intentions. Journal of Business Venturing, 15, 411-432.

Kolvereid, L., \& Isaksen, E. (2006). New business start-up and subsequent entry into self-employment. Journal of Business Venturing, 21(6), 866-885.

Laguna, M., Moriano, J.A., Roznowki, B., Gómez, A. (2008). Entrepreneurship in Polish and Spanish students explained by means of the theory of planned behavior. Studia Psychologiczne (Psychological Studies), 46, 27-40.

Moriano, J. A. (2005). El perfil psicosocial del emprendedor [The psychosocial profile of the entrepreneur]. Madrid: Consejo Económico y Social.

Movahedi, R., Fathi, H. (2011). Assessing agricultural students' attitude towards entrepreneurship. International Journal of Agriculture. Research and Review, 1(4), 168-173.

Nasurdin, A. M., Ahmad, N. H., Lin, C. E. (2009). Examining a model of entrepreneurial intention among Malaysians using SEM procedure. European Journal of Scientific Research, 33 (2), 365-373.

Noel, T. (1998). Effects of entrepreneurial education on intent to open a business: An exploratory study. Journal of Entrepreneurship Education, 5, 3-13.

Rotefoss, B., Kolvereid, L. (2005). Aspiring, nascent and fledgling entrepreneurs: An investigation of the business start-up process. Entrepreneurship \& Regional Development, 17, 109-127.

Shiri, N., Mohammadi, D., Hosseini, S. M. (2012). Entrepreneurial Intention of agricultural students: effects of role model, social support, social norms and perceived desirability. scholars research library. Archives of Applied Science Research, 4(2), 892-897.

Souitaris, V., Zerbinati, S., Al-Laham, A. (2007). Do entrepreneurship programmers raise entrepreneurial intention of science and engineering students? The effect of learning, inspiration and resources. Journal of Business Venturing, 22(4), 566-591.

Van Gelderen, M., Brand, M., Van Praag, M., Bodewes, W., Poutsma, E., van Gils, A. (2008). Explaining entrepreneurial intentions by means of the theory of planned behavior. Career Development International, 13, 538559. Doi: 10.1108/13620430810901688. 


\section{Abstrakt (in Polish)}

Niniejszy artykuł bada przedsiębiorcze intencje wśród absolwentów kończq̨cych USM Engineering Campus. Stosując Teorię Planowanego Zachowania (TPB; Ajzen), zbadaliśmy model empiryczny determinant przedsiębiorczych intencji. Chociaż prowadzono już badania nad przedsiębiorczymi intencjami, niewiele badań dotyczy absolwentów uczelni znajdujących się poza granicami kraju. Nasze badanie ma na celu wypetnienie tej luki przy użyciu Kwestionariusza Przedsiębiorczych Intencji (EIQ, wersja 3.1). Ankietq objęto irańskich absolwentów USM Engineering Campus, stosujqc metodę cenzusu. Autorzy proponuja model empiryczny. Sprawdzili jego wiarygodność i ważność, stosujqc modelowanie strukturalne równania. Dane analizowano przy użyciu oprogramowania SPSS16 i Amos18. Wyniki pokazały, że poziom wiedzy o źródłach pomocy dla przedsiębiorców oraz składniki TPB wpływajg na przedsiębiorcze intencje. Empiryczny model dobrego dopasowania wskazuje na dobre dopasowanie modelu $\chi 2=1.047, d f=2$, prawdopodobieństwo 0.592; NFI=0.981; CFI= 1.000; RMSEA=0.000. Wydaje się, że aktualny model empiryczny może być drogowskazem dla przyszłych badań nad tym ważnym tematem.

Słowa kluczowe: przedsiębiorcze intencje, modelowanie strukturalnych równań, absolwenci, TPB. 